<原 著 $>$

Immunoblot 法を用いた肝組織内 B 型肝炎ウイルス c,e， pre-S1/S2, x ポリペプタイドの検索

$\begin{array}{llllll}\text { 横須賀 収 } & \text { 小俣 } & \text { 政男 } & \text { 伊藤よしみ } & \text { 松山 } & \text { 泰久 } \\ \text { 林 な注子 } & \text { 奥田 } & \text { 邦雄 } & \text { 大藤 } & \text { 正雄* } & \end{array}$

要 旨：B 型慢性肝疾患25例, 非 B 型肝疾患 5 例を対象とし肝組織中の B 型肝炎ウイルス c, e, pre-S1/S2，x 抗原ポリペプタイドを immunoblot 法にて検索した，c，e 抗原性を有するぺ プタイドは22kd，19kd，15kdの部位に検出された。 c/e ペプタイドは血中 e 抗原陽性12例中11 例, e 抗原抗体陰性 6 例中 2 例, e 抗体陽性 7 例中 0 例に検出された. Pre-S1/S2抗原ペプタイ ドはそれぞれ $42,39 \mathrm{kd} / 36,33 \mathrm{kd}$ の部位に検出された. Pre-S1，S2抗原ベプタイドは e 抗原陽 性12例中それぞれ10例及び12例，e 抗原・抗体陰性 6 例中 1 例及び 3 例，e 抗体陽性 7 例中 2 例 及び 5 例において検出された. 血中 e 抗原陽性例では c, e, pre-S1/S2ペプタイドの合成が行な われ完全なウイルス粒子が生成されると考えられる。一方, e 抗体陽性例の多くでは pre-S1/S2 ペプタイドは合成されているすのの c, e 抗原ペプタイドは合成されず完全なウイルス粒子は生 成されえないと考えられた。

臬引用語： Immunoblot 法 $\mathrm{HBc}$ 抗原ポリペプタイド $\mathrm{HBe}$ 抗原ボリペプタイド Pre-S1/S2抗原ポリペプタイド＼cjkstart慢性肝疾患

\section{緒言}

著者らは既に肝組織内の B 型肝炎ウイルス DNA (HBV DNA) ${ }^{1,2)}$, RNA transcripts ${ }^{3}$ kついて検索し, 肝内に打けるゥイルス核酸の存在形態を明らかにし た。しかしがら mRNAからの合成産物である各種 B 型肝炎ウイルスボリペブタイドに関する知見はこれ まで主として血中ウイルスを純化抽出する事により得 られており4て6), 䀒内におけるウイルスポリベプタイド を直接検索した報告は少ない，今回，著者らは肝生検 にて得た肝組織内における c, e, pre-S1/S2, x 抗原ポ リベブタイドを検索し，ウイルスDNA，RNAの存在 形態との関連について考察した。

\section{対象及び方法}

僈性肝疾患患者より得た肝生検標本30検体（血中 HBs 抗原陽性25検体，陰性 5 検体）を対象とした (Table 1). 肝組織標本は採取後直ちに $-80^{\circ} \mathrm{C}$ に保存 した. 各種ポリペブタイドの検索は標本(3〜10mg wet tissue)を $1 \%$ Nonidet P40，0.5\%デオキシコール酸，

\footnotetext{
* 千葉大学医学部第 1 内科
}

〈受付日62年 9 月17日 $>$
Table 1 Histological findings of 30 specimens analyzed by immunoblotting method.

\begin{tabular}{r|c|c|c|c}
\hline & CPH & CAH & $\begin{array}{l}\text { Cir- } \\
\text { rhosis }\end{array}$ & Total \\
\hline HBsAg +ve eAg+/eAb- & 5 & 5 & 2 & 12 \\
$\mathrm{eAg}-/ \mathrm{eAb}-$ & 1 & 1 & 4 & 6 \\
$\mathrm{eAg}-/ \mathrm{eAb}+$ & 3 & 1 & 3 & 7 \\
$\mathrm{HBsAg}-\mathrm{ve}$ & 3 & 1 & 1 & 5 \\
\hline
\end{tabular}

$20 \mathrm{mM}$ Tris- $\mathrm{HCl}(\mathrm{pH} 7.5), 20 \mathrm{KIU} / \mathrm{m} l$ アプロチニン 中にてホモジート後，10,000 rpm 10分間遠心し，上 清中の蛋白を Lowry 法?にて定量して行なった. 各検 体あたり $20 \mu \mathrm{g}$ の蛋白を $1 \% \mathrm{SDS}, 2.5 \%$ メルカプトエ タノール中にて $100^{\circ} \mathrm{C} 5$ 分間処理後12.5\%SDS-PAGE にて泳動した. 分子量のマーカーとして既知の分子量 マーカー(BRL 社製)を使用した. SDS-PAGEにて泳 動展開したゲル中のポリペブタイドはニトロセルロー 不膜に電気的に移行泉後，以下に述べる各種抗体を用 いて immunoblotを行ない, diaminobenzidine にて発 色検出した。

c 抗原性, e 抗原性を有するボリペプタイドの検索は 
pre-s1 pre-s 2

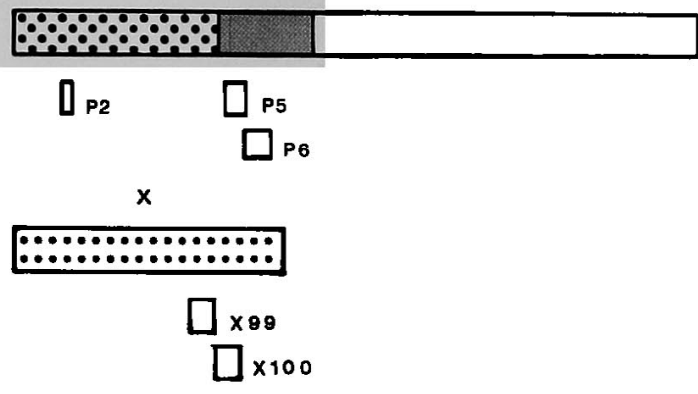

Fig. 1 Correlation between the pre-S1/S2/S, $x$ polypeptides and synthetic peptides $\mathrm{P} 2, \mathrm{P} 5, \mathrm{P} 6$, $\mathrm{X} 99, \mathrm{X} 100$.

それぞれポリクローナル抗 HBc 抗体 (DAKO 社製)， モノクローナル抗 $\mathrm{HBe}$ 抗体 (ミドリ十字社製) を用い た. Pre-S抗原ポリペプタイドの検索には Fig. 1 に示 す如く pre-S1開始部位からそれぞれ第28～34(P2)，第 $124 \sim 135$ (P5)，第133～148 ア ミ 酸残基（P6）に対応 する合成ぺプタイドに対する抗体を用いて行なった。 また $\mathrm{x}$ 抗原ポリペプタイドは $\mathrm{x}$ 抗原開始部から第 100１15 (X99)，第115 130 ア 酸残基（X100）に 対応する合成べプタイドに対する抗体を用い検索した (Fig. 1).

\section{結果}

抗 $\mathrm{HBc}$ 抗体に上る検索に上り, immunoblot 上 22 キ ロダルトン (kd)，19kd，15kd の部位にc 抗原性有 するポリペプタイドが検出された（Fig. 2). c 抗原性 を有するポリペプタイドは血中 e 抗原陽性12検体中11 検体 (92\%), e 抗原・抗体両者陰性 6 㭘体中 2 㭘体 (33\%)，e 抗体陽性 7 検体中 0 検体 (0\%) に検出され た。血中 HBs 抗原陰性 5 例においては検出されな かった (Table 2).

抗 $\mathrm{HBe}$ 抗体による検索によっても immunoblot 上 22kd, 19kd, 15kd の部位にe 抗原性を有するボリへプ タイドが検出された (Fig. 2).

e 抗原性を有するポリベブタイドは血中 HBe 抗原 陽性12例中11例 (92\%), e 抗原・抗体陰性 6 例中 2 例 (33\%), e 抗体陽性 7 例中 0 例 (0\%) に検出された. 血中 HBs 抗原陰性 5 例においては 1 例子検出されな かった。これら22kd, 19kd, 15kdのポリべプタイドは c抗原及び e 抗原エビトープを有すると考えられた。

又抗 pre-S 抗体を用いた検索のらち第133〜148ア ミ /酸残基 (Fig. 1の P6) に対応する抗体を用いる事に より 42kd, 39kd, 36kd, 33kd の部位に pre-S1/S2抗原
29巻 4 号（1988）
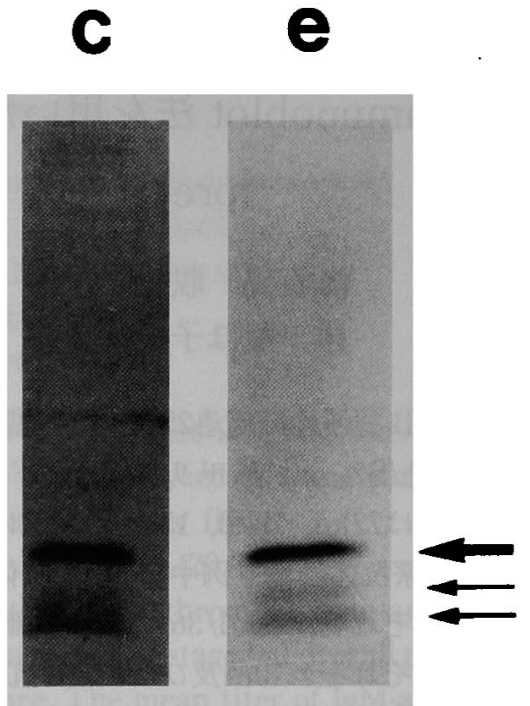

Fig. 2 Representative figure of core, e antigen polypeptides in immunoblot. Arrows indicate 22 kilodalton (thick arrow), 19 and 15kilodalton (thin arrows).

Table 2 Positive rate of c, e, pre-S1, pre-S2 polypeptides in 30 specimens in comparison with serum HBV markers.

\begin{tabular}{r|c|c|c|c}
\hline & c & e & pre-S1 & pre-S2 \\
\hline HBsAg +ve eAg+/eAb- & $11 / 12$ & $11 / 12$ & $10 / 12$ & $12 / 12$ \\
eAg-/eAb- & $2 / 6$ & $2 / 6$ & $1 / 6$ & $3 / 6$ \\
eAg-/eAb+ & $0 / 7$ & $0 / 7$ & $2 / 7$ & $5 / 7$ \\
$\mathrm{HBSAg}$-ve & $0 / 5$ & $0 / 5$ & $0 / 5$ & $0 / 5$ \\
\hline
\end{tabular}

性を有すると思われるボリペプタイドが検出された (Fig. 3).第124 135 アミノ酸残基 (Fig. 1の P5) に 対応する抗体を用いては pre-S 抗原性を有するポリン プタイドは特定できなかった，Pre-S1抗原ボリベブタ イド(P42，P39)は血中 e 抗原陽性12例中10例(83\%)， $\mathrm{e}$ 抗原 - 抗体除性 6 例中 1 例 (17\%), e 抗体陽性 7 例 中 2 例 (29\%) に険出された。.Pre-S2抗原は血中 e 抗 原陽性12例中12例全例 $(100 \%)$ K, e 抗原・抗体除性 6 例中 3 例 $(50 \%)$, e 抗体陽性 7 例中 5 例 $(71 \%) k$ 検出された. Pre-S2シグナルは e 抗原陽性例に比し, $\mathrm{e}$ 抗原・抗体陰性, e 抗体陽性例は弱い㑯向を示した。 又血中 $\mathrm{HBs}$ 抗原陰性 5 例においては検出されなかっ た (Table 2).

$\mathrm{x}$ 抗体を用いた検索では第100〜115（X99），第 115 130アミ 酸残基（X100）に対する抗体を用いて， 


\section{a}
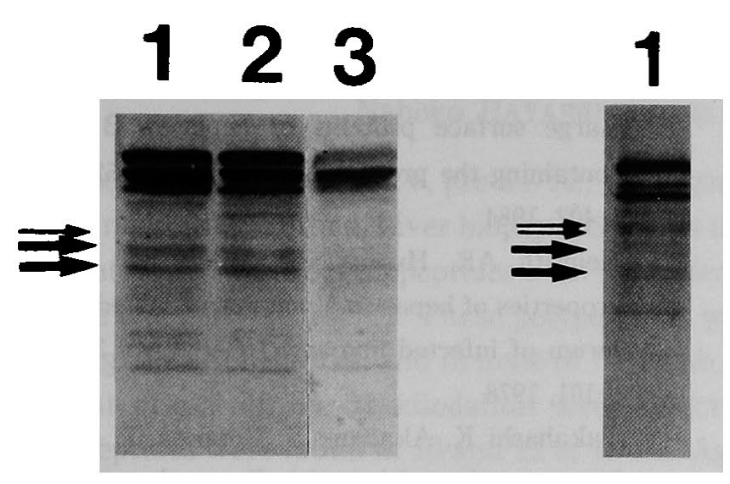

Fig. 3 Representative figure of pre-S1/S2 polypeptides in immunoblot. Lanes 1, 2 (panel a) and lane 1 (b) are $\mathrm{HBeAg}$ seropositive, and lane 3 (a) is $\mathrm{HBeAb}$ seropositive cases. Thin arrows indicate the pre-S1 polypeptides and thick arrows indicate the pre-S2 polypeptides.

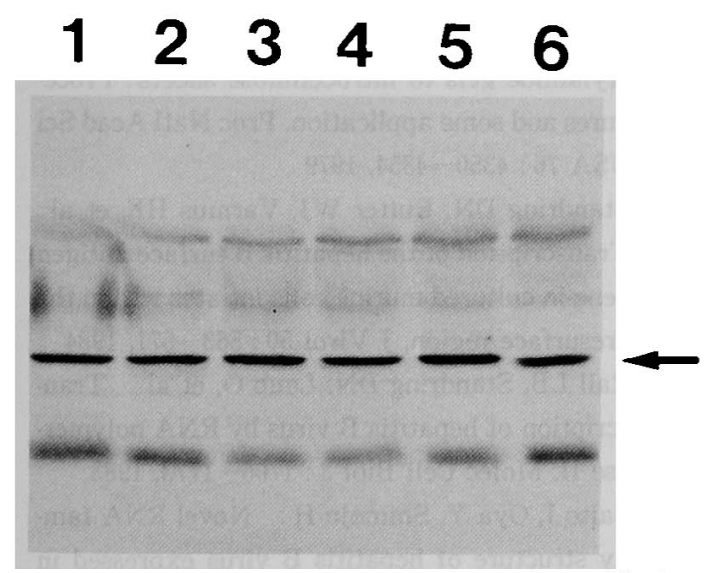

Fig. 4 Representative figure of $x$ polypeptide in immunoblot. Lanes 1, 2 are HBsAg seronegative, lanes 3, 4 are $\mathrm{HBeAg}$ seropositive and lanes 5, 6 are $\mathrm{HBeAb}$ seropositive cases. Arrow indicates the position of $28 \mathrm{kilodalton}$.

それぞれ28kd，17kd にシクナルが認められたが HBs 抗原陰性の症例に括いて子同部位にバンド状に認めら れ非特異バンドと考党られた（Fig. 4).

\section{考 案}

著者らは䵊量の肝生検標本 (3mg 10mg)を用い， immunoblot 法により, 肝内に和ける c, e, pre-S抗原 性を有するポリペブタイドの検索を行ない，その分子
形態を明らかにしらる事を示した。

c 及び e 抗原性を有するポリベプタイドは22kd，19 kd, 15kdの部位に検出されこれらのポリペプタイド はそれぞれcと e 双方の抗原性を有すると考劣られ た. Takahashi $ら^{6}$ は血中 virion 由来の core 粒子中 にe 抗原性もみられる事を明らかにしているが，今回 の成績は肝内においても同一ポリペプタイドに $\mathrm{c}, \mathrm{e}$ 双 方の抗原性がみられる事を明らかにし得たと考える。 あた，最も強いシグナルである22kdのポリペプタイド は血液由来のウイルス粒子から抽出した core ポリペ プタイドのサイズとほぼー致して拈り core 粒子の majorポリペプタイドと考えられた.

今回の椧索では c, e 抗原性を有するポリベプタイド は血中 e 抗原陽性例に主として検出されたが, e 抗体 陽性例では恰出できなかった。一方 pre-S2抗原ポリペ プタイドは e 抗原陽性例では全例に検出され, 更に $\mathrm{e}$ 抗体陽性例でも71\%と高率に検出された．e抗原陽性 例では注注全例に各種増殖段階にある組み込まれてい ないfreeの HBV DNA が検出されることから coremessenger RNA と S-messenger RNA 双方が転写さ れており ${ }^{3)}$, したがってc, e 抗原, pre-S1/S2及びs抗 原ポリペプタイドを含む完全なウイルス粒子の生成が 予想される.これに対し, e 抗体陽性例では各種増殖過 程における free の HBV DNA 検出頻度は低くしばし ばウイルス DNAがヒト DNA に組み込まれている為 にS-messenger RNAのみが険出され, coremessenger RNA は検出できにくい3). ウイルス DNA がヒトDNAに組み込まれた場合 c, e 抗原を codeす るDNAはしばしば欠損しており c/e 抗原系の messenger RNA は当然転写され得ない。一方, pre-S1/S2 ポリペプタイドに関しては今回の検索からは e 抗体陽 性例でウイルス DNA が組み込をれていてす pre-Sを codeするDNAが保存され，それから pre-S1/S2ポリ ペプタイドが産生されている事が示された. pre-S2ポ リペブタイドを codeする mRNA は pre-S2開始コド ンの17base 上流から転写される S-messenger RNA と考えられ，この mRNAから pre-S2ポリペプタイド とsボリベプタイドの双方が産生されると考学られ る9). Pre-S2の mRNAの転写開始部位はウイルス DNA の組み込み部位が集中しているウイルス Direct repeat 近傍から約1.3キロ base 離れており, ウイルス DNA の組み込みが起こった場合でも保存される可能 性が高く, その結果 pre-S2ポリペプタイドが高率に産 生されているすのと考学られた. 又 pre-S1ポリペプタ 
イドを codeする mRNA は RNA polymerase II を用 いた in vitroの transcriptionの実験 ${ }^{(0)}$ ，或いは expression vectorによる pre-S1ポリベブタイド発現 時の RNAの解析から pre-S1關始コドンの約38base 上流から転写が開始されるといら報告11があり，この 場合 pre-S1ポリペプタイドの mRNA を転写しらる DNA は組み込みに際して保存され pre-S1ポリペプタ イドが産生されらると考劣れれる。しかしながら，こ の in vitroの系でみられる mRNA の存在は生体内で は末だ確認されておらず, 生体内では微量にしか存在 しないか, 或いは実際には存在せず pre-S1ボリベプタ $1 ト ゙ は$ core-messenger RNAから産生される可能性 も残されている. 今回の検索では e 轨原陰性例に括け る pre-S1ポリベプタイドの検出率は pre-S2ポリペブ タイドに比し低頻度であり，低レベルの message を反 映するむのと考えられた. Pre-S1/S2, c, e抗原ポリぺ ブタイドに関する今回の成績はウイルス DNA の存在 状態（組み込みの状況）と RNA transcripts の転写, ポリペプタイドの生成との関連を裏付けるものと考え られた。

x 抗原ポリペプタイドに関して Moriarty らは遺厷 子上から想定されるx抗原ポリベプタイドの第 100 115，144～154 アミ，酸残基に対応する合成ペプ タイドを作製しこれに対する抗体を用いて28kd の $\mathrm{x}$

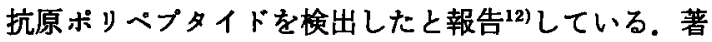
者らは第100～115，115～130 アミノ酸残基に対応する 抗体を用いて28kd, 17kdのシグナルを検出したが, 非 B 型肝炎 5 例においてもシグナルが検出された. Moriarty らの報告した $28 \mathrm{kd}$ のシタナルは非特異的なるの であった可能性が強いと考党られた。

文 献

1) Yokosuka $O$, Omata $M$, Imazeki $F$, et al: Active and inactive replication of hepatitis $B$ virus deoxyribonucleic acid in chronic liver disease. Gastroenterology 89 : 610-616, 1985

2) Omata $M$, Yokosuka $O$, Imazeki $F$, et al: Correlation of hepatitis $B$ virus DNA and antigens in the liver. A study in chronic liver disease. Gastroenterology 92 : 192-196, 1987
3) Yokosuka O, Omata $M$, Imazeki $F$, et al: Hepatitis B virus RNA transcripts and DNA in chronic liver disease. New Engl J Med 315: 1187 $-1192,1986$

4) Heerman KH, Goldmann U, Schwartz W, et al : Large surface proteins of hepatitis B virus containing the pre-S sequence. J Virol 52: 396 $-402,1984$

5) Neurath $A R$, Huang $S N$, Strick $N$ : Some properties of hepatitis $B$ antigens isolated from serum of infected humans. J Gen Virol 39 : 91 $-101,1978$

6) Takahashi $\mathrm{K}$, Akahane $\mathrm{Y}$, Gotanda $\mathrm{T}$, et al: Demonstration of hepatitis $\mathrm{B}$ e antigen in the core of Dane particles. J Immunol 122: 275 $-279,1979$

7) Lowry OH, Rosebrough NJ, Forr AL, et al: Protein measurement with the phenol reagent. J Biol Chem 193 : 265-273, 1951

8) Towbin H, Staehein T, Gordon J : Electrophoretic transfer of proteins from polyacrylamide gels to nitrocellulose sheets : Procedures and some application. Proc Natl Acad Sci USA 76 : 4350-4354, 1979

9) Standring DN, Rutter WJ, Varmus HE, et al: Transcription of the hepatitis $B$ surface antigen gene in cultured murine cells intiates within the presurface region. J Virol 50 : 563-571, 1984

10) Rall LB, Standring $D N$, Laub $O$, et al : Transcription of hepatitis $B$ virus by RNA polymerase II. Molec Cell Biol 3 : 1766-1773, 1983

11) Saito I, Oya Y, Shimojo H : Novel RNA family structure of hepatitis B virus expressed in human cells, using a helper-free adenovirus vector. J Virol 58 : 554-560, 1986

12) Moriarty AM, Alexander $H$, Lerner RA, et al ; Antibodies to peptides detect new hepatitis B antigens: Serological correlation with hepatocellular carcinoma. Science $227: 429-433$, 1985 


\title{
The detection of hepatitis B virus core, e, and pre-S1/S2 antigen polypeptides in liver tissue by immunoblot
}

\author{
Osamu Yokosuka, Masao Omata, Yoshimi Ito, Yasuhisa MatsuYama, \\ Nahoko HAYASHI, Kunio OKUDA and Masao OHTo*
}

\begin{abstract}
Hepatitis B virus core, e, pre-S1/S2, $\mathrm{x}$ antigen polypeptides in liver tissue were examined by the immunoblotting method. Liver biopsy specimens taken from $25 \mathrm{HBsAg}$ seropositive and 5 seronegative patients were studied. Polypeptides with the molecular weight of $22,19,15$ kilodalton were detected by both e and core antibodies. These polypeptides were found in 11 of $12 \mathrm{HBeAg}$ seropositive, in 2 of 6 $\mathrm{HBeAg} / \mathrm{Ab}$ seronegative, and in none of $7 \mathrm{HBeAb}$ seropositive cases. Polypeptides with the molecular weight of $42,39,36,33$ kilodalton were detected by the anti-pre-S antibody. Pre-S1 and pre-S2 polypeptides were found in 10 and 12 of $12 \mathrm{HBeAg}$ seropositive, in 1 and 3 of $6 \mathrm{eAg} / \mathrm{eAb}$ seronegative, and in 2 and 5 of $7 \mathrm{HBeAb}$ seropositive cases. The hepatitis B virus core, e, and pre-S1/S2 antigen polypeptides seems to be actively synthesized in the liver of HBeAg seropositive cases, where as in the liver of $\mathrm{HBeAb}$ seropositive cases only the pre-S1/S2 antigen polypeptides are synthesized therefore the synthesis of the complete virion seems to be prohibited.
\end{abstract}

* The First Department of Medicine, Chiba University School of Medicine (Chiba) 